\title{
DEVELOPMENT OF WEBCOMIC LEARNING MEDIA OF WEBSITE MATERIALS IN XI CLASS OF ONLINE BUSINESS AND MARKETING
}

\author{
Raya Sulistyowati1; Tri Sudarwanto2; Indy Astira Kause Putri³ \\ Faculty of Economics, Universitas Negeri Surabaya \\ Email : rayasulistyowati@unesa.ac.id
}

\begin{abstract}
The digital age has fierce competition for schools to prepare students, especially in the cognitive aspects. The facts found in the potential and problems show that there are still many students who do not understand the material in Evaluating Website Basic Competencies. The purpose of this study was to determine the development process, the feasibility of the media and students' responses to webcomic learning media. The study chose the 4D research model adapted from Thiagarajan (1974) using data collection techniques in the form of observations and questionnaires. The research subjects were taken as many as 8 people (limited test) and 20 people (field test) in XI class of Online Business and Marketing. The results of the evaluation of the validators had a presentation of $87 \%$. Furthermore, the trial phase was limited to a percentage of $85 \%$, at the trial stage a large percentage of $92 \%$. Increasing the percentage of students' responses can be one of the references that webcomic learning media is worthy of being one of the supporting learning media when learning takes place.
\end{abstract}

Keywords: Learning Media, Webcomic, Marketing

\section{INTRODUCTION}

The presence of technology has a significant impact on various aspects. As for the aspect of education, it becomes an increase to do learning with the help of digitization (Richardus, 2011: 5). Digitalization assistance in education is often said to be 21st-century competence or the 4.0 industrial revolution. 21st Century competence has its impacts and challenges for schools, especially Vocational High Schools (Pretty, 2018: 36). The challenge for students is to be able to read, understand, analyze and manage information in the realm of digitalization to be applied in learning process both inside and outside school (Yahya, 2018: 14).

Under the challenges in digitalization, educators are encouraged to adapt and develop skills to innovate in learning media (Vebrianto and Osman, 2011). The utilization of digital technology for learning media following the current era is visual media (Arsyad, 2017: 11). Sudjana believed that a human brain can see and capture color images faster than colorless images. Basically, not all humans can choose the choice of color images as an alternative to understand an understanding. However, the presence of color images can produce the examples needed to understand something (2017: 13).

Based on observations on research subjects, the teaching and learning process using learning media that was designed on cognitive aspects had its advantages and disadvantages. In the teaching and learning process in the classroom, educators would teach using powerpoint media supported by teaching materials to measure as well as to strive so that students' understanding had increased. Meanwhile, students were accustomed to using internet media as a guide in understanding the material if the media from the educator was considered to be 
less detailed and clear. To strengthen this fact, the researchers used an online questionnaire for 20 people with the results stating that they were less able to understand the material from the media provided by educators in the classroom.

Explanation of problems that have existed before then offered a webcomic in the classroom. The webcomic position in learning is as a supporting medium in the cognitive aspects of students in the classroom. According to Rima (2016: 3), students' understanding has gradually increased. This understanding can be affected by the media used in learning so that if it increases then the media is considered involved in the cognitive of students (Plass and Kaplan, 2016). In this case, webcomic can be accessed via www.webcomic.com. The website is conditioned to not display content outside the indicators of competency achievement in the material. Besides, the media displays an evaluation following the thinking power of students that can be downloaded for free. In accordance with schools that have wifi facilities, the media can be accessed offline so that students can understand again when outside the school.

A webcomic is designed according to the characteristics, environment and facilities and infrastructure available in schools. Besides, this media includes dialogue, cartoon drawings, website examples, website types, and evaluations to be able to improve students' thinking abilities. In this media, it is input the core competencies, basic competencies, indicators of competencies achievement, learning objectives so that students can know the objectives in studying the material in Basic Competencies 3.2 Evaluating the Website. The packaging with a simple conversation and the situation of the main character and other figures under the validation expert can attract the attention of students so that they are enthusiastic in participating in learning.

A webcomic is a media or container that is used as a distributor or transmitter of learning by educators that can be done through smartphones. The media uses a hosting or site that is obtained for free by changing the domain so it can be accessed free of charge by the general public. The general public can cover large areas in Indonesia with smooth and stable internet access to access this site (Bagus, 2017: 103). The research had problems that are used as research that knows the process of developing webcomic learning media, knowing the feasibility of developing webcomics and knowing students' responses after using media in learning.

Webcomic media can be accessed via smartphones in the form of Android and iOS adapted to the situation of students and the school environment that can access WiFi. Webcomic has material explanations in the form of images and dialogues that can be used online and downloaded so that students can understand the explanations contained therein. Students are expected to look for material by accessing it via smartphone while learning and evaluating on the website so they can improve the cognitive abilities of students.

\section{METHOD}

The method used to support the implementation of this research was the method of development or Research and Development (R\&D). This research method was used to produce certain products and tested the effectiveness of these products. The type of this method was assisted by a 4-D or 4-P development model called defining, 
designing, developing and distributing (Rochmad, 2012: 60). This study took a target or object, that were students in XI class of Online Business and Marketing at SMK Negeri 2 Buduran. The trials were divided into two classes. Small classes or limited trials were given to eight students. Meanwhile, field trials or large classes were given to 20 students. The research target qualifications were students having a smartphone and aged 16-18 years (Gafur, 2012: 125).

Data collection used an instrument sheet in the form of a validation sheet of three experts and a student questionnaire response sheet. The authority of the media validator was owned by the material validator, the media, and language validator following the provisions in the assessment of a media. According to Trianto, this validation was carried out to obtain the quality of instructional media before getting students' responses (2014: 92). This method was supported by qualitative and quantitative calculations so that it could produce balanced and accountable data. Qualitative analysis was carried out on the validation sheet and the student questionnaire response sheet. The researcher used a Likert scale in the expert validation process. Sudaryono argued that this scale could measure indicators as benchmarks in research (2013: 49). While the response used the Guttman scale measurement type. This scale could give researchers confidence to measure the attitude of the research object (Sugiyono, 2015: 15).

\section{RESULT \& DISCUSSION}

As previously explained that the webcomic was created following the age, characteristics of students, facilities, and infrastructure available in schools and smartphones with Android and iOS types that can access the webcomic website. On observation or direct observation, webcomics could be accessed properly in the classroom because students had good conditions in internet connections and the projector's LCD could function to display material to be taught. This meant that the teacher had a role as a facilitator and taught so that students were not left alone during the learning process and the learning objectives could be achieved properly.

In this study, the process of evaluating the feasibility of a webcomic was assessed by several competent experts and experts in their fields. Some of these experts provided an assessment to determine whether this webcomic was valid or not to be used as learning media on the material in the Website Competency Evaluation Base. This media was considered valid if some experts claim that this media had a very feasible category or was suitable for use as a teaching medium, meaning that the media was feasible to use without revision or with little revision. The results of the assessment/validation by Material, Language and Media experts which were presented in the following Table:

Table 1. Expert Validation Results

\begin{tabular}{llll}
\hline No. & Component & Presentation & Appropriateness \\
\hline 1. & Material Worthiness & $89 \%$ & Very decent \\
2. & Language Feasibility & $89 \%$ & Very decent \\
3. & Media Feasibility & $84 \%$ & Very decent \\
\hline Overall average & $87 \%$ & Very decent \\
\hline
\end{tabular}


The data above was taken through the analysis that the point of 'media feasibility' had a different percentage than the feasibility of other experts because webcomic media had a story concept that needs to be improved in quality so that it could be well received by students in the classroom. This was based on the opinion of Sudjana (2017: 14), that the picture does not have a permanent nature in terms of learning and attracting interest, so educators need to think about how students can receive the material well and cognitive aspects can be reached properly. From the steps implemented to develop media, the webcomic media can be found that the development process will improve quality due to syllabus, lesson plans, indicators of competency achievement, learning objectives, learning media materials, and the school environment.

The results of the responses of students in limited trials and the field were:

Table 2. Student Response Results

\begin{tabular}{llll}
\hline No. & Trial Form & Presentation & Appropriateness \\
\hline 1. & Limited Trial & $85 \%$ & Very good \\
2. & Field Trial & $92 \%$ & Very good \\
\hline Overall average & $88.5 \%$ & Very good \\
\hline
\end{tabular}

In limited trials, researchers got a smaller percentage than field trials. This related to the results of the media with the indicators "character selection, dialogue and fonts" when the research took place in the classroom. Webcomics needed to be reviewed regularly by media managers to produce a nice and neat appearance so that students could read and understand them. Thus, the media could influence the ability or students' way of thinking. Moreover, educators could produce learning goals that were appropriate for students in the classroom.

The result of the response of students in small class trials was $85 \%$ or 'very good'. According to Riduwan (2016: 13), the validation interpretation reached a percentage of $>61 \%$ so it could be concluded as good. The result of the response of students in large class trials was $92 \%$ or 'very good'. According to Riduwan (2016: $13)$, the validation interpretation reached a percentage of $>61 \%$ so it could be concluded as good.

\section{CONCLUSION}

Webcomic learning media that had been through the process and developed in the review, revision, and validation with a percentage of $87 \%$ or 'Very Eligible'. The result of material validation was $89 \%$ with the criteria 'very feasible'. The results of language validation obtained an assessment of $89 \%$ with the criteria 'very feasible'. The results of media validation had an assessment of $84 \%$ with the criteria 'very feasible'. Highest score on eligibility results. Webcomic learning media successfully developed using the Four Model or 4-D model, namely Define, Design, Develop, Disseminate. This development phase was adapted from Thiagarajan, Semmel and Semmel. However, it was re-adapted by Trianto with 4-P. At the stage of dissemination was not done because the media had not included the response of students and the need for large-scale research. At points that were in the material and language aspects, this could be a supporter in the media so that would not only have interesting images but also good material and language management to be able 
to have an attraction in student learning interests. At the Development Testing stage, webcomic media had a student response results in a limited trial (small class) was 85\%. While the response of students in field trials reached $92 \%$. Student responses had the highest value on aspects of instructional quality or assistance in learning so that webcomic media was considered feasible in the learning process. Furthermore, Educators were expected to supervise students in the use of webcomic media using smartphones to access the internet. It aimed to keep students focused on the learning being carried out by educators.

\section{REFERENCES}

Annielson., Gabriela., Ana., 2016. The Comic As Teaching Strategy In Learning Of Students In An Undergraduate Management Program. Mackenzie Management Review, 18(1). ISSN 1678-6791.

Arsyad, A., 2017. Media Pembelajaran. Jakarta: Raja grafindo Persada. ISBN 9794215473.

Bagus, D., 2017. Pengembangan Mobile Webtoon Pada Mata Kuliah Pemrograman Game Di Universitas Negeri Surabaya, Jurnal Informatika, 2 (1), 103.

Direktorat Pembinaan SMK., 2018. Pedoman Praktik Kerja Lapangan (PKL) Peserta Didik SMK. Jakarta: Kementerian Pendidikan dan Kebudayaan.

Gafur, A., 2012. Desain Pembelajaran: Konsep, Model, dan Aplikasinya dalam Perencanaan Pelaksanaan Pembelajaran. Yogyakarta: Ombak. ISBN 9786027544352.

Kementerian Pendidikan dan Kebudayaan., 2016. Empat Perbaikan Kurikulum 2013. Media Komunikasi dan Inspirasi Jendela Pendidikan dan Kebudayaan, 3(6), 3-4.

Peraturan Menteri Pendidikan dan Kebudayaan Republik Indonesia Nomor 60., 2014. Kerangka Dasar dan Struktur Kurikulum Sekolah Menenengah Kejuruan/ Madrasah Aliyah Kejuruan. Jakarta: Kementerian Pendidikan Nasional.

Pretty., 2018. Tantangan Revolusi Industri 4.0 Untuk SMK.Berita Direktorat Pembinaan SMK. Diperoleh pada 1 Agustus 2019, dari http://psmk.kemdikbud.go.id/konten/3854/tantangan-revolusi-industri-40untuk-smk.

Rochmad., 2012. Desain Model Pengembangan Matematika, Jurnal Matematika Kreatif-Inovatif, 3 (1), 60-71.

Richardus., 2011. Menjawab Tantangan Pendidikan Abad 21. Surabaya: APTIKOM

Riduwan., 2015. Skala Pengukuran Variabel-variabel Penelitian. Bandung: Alfabeta. ISBN 9798433084.

Rima, E., 2016. Ragam Media Pembelajaran. Kata Pena. ISBN 9786021296271

Rochmad., 2012. Desain Model Pengembangan Matematika, Jurnal Matematika Kreatif-Inovatif, 3 (1), 60-71.

Sudaryono, dkk., 2013. Pengembangan Instrumen Penelitian Pendidikan. Yogyakarta: Graha Ilmu.

Sudjana, N., 2017. Media Pengajaran. Bandung: Sinar Baru Algesindo.

Sugiyono., 2015. Metode Penelitian dan Pendidikan. Bandung: CV Alfabeta. ISBN 9798433718.

Tim APJII. (Ed)., 2018. Potret Zaman Now Pengguna dan Pelaku Internet Indonesia !. Jakarta : Buletin APJII. 
Tim EMS., 2012. Web Programming For Beginners. Jakarta: PT Elex Media Komputindo.

Trianto., 2014. Mendesain Model Pembelajaran Inovatif, Progresif dan Kontekstual. Jakarta: Prenadamedia Group. ISBN 9786021186053 Jurnal Pendidikan Tata Niaga (JPTN) Volume 07 No 02 Tahun 2019 ISSN 2337-6078.

Plass, J.L., Kaplan, U., 2016. Emotional Design in Digital Media for Learning, in: Emotions, Technology, Design, and Learning. Elsevier, pp. 131-161. https://doi.org/10.1016/B978-0-12-801856-9.00007-4.

Vebrianto, R., Osman, K., 2011. The effect of multiple media instruction in improving students' science process skill and achievement. Procedia - Soc. Behav. Sci. 15, 346-350. https://doi.org/10.1016/j.sbspro.2011.03.099.

Yahya, M., 2018. Era Industri 4.0 Tantangan dan Peluang Perkembangan Pendidikan Kejuruan Indonesia. Sidang Terbuka Luar Biasa Senat Universitas Negeri Makassar, Universitas Negeri Makassar. 